Abstracta Iranica Abstracta Iranica

Revue bibliographique pour le domaine irano-aryen

Volume 26 | 2005

Comptes rendus des publications de 2003

\title{
« Of Jewels and Horses: the Career and Patronage of an Iranian Merchant under Shah Jahan ». Iranian Studies 36, 2 (2003), pp. 213-240.
}

\section{Colin Mitchell}

\section{(2) OpenEdition}

1 Journals

\section{Édition électronique}

URL : http://journals.openedition.org/abstractairanica/2757

DOI : 10.4000/abstractairanica. 2757

ISSN : 1961-960X

Éditeur :

CNRS (UMR 7528 Mondes iraniens et indiens), Éditions de l'IFRI

\section{Édition imprimée}

Date de publication : 15 mai 2005

ISSN : 0240-8910

Référence électronique

Colin Mitchell, « « Of Jewels and Horses: the Career and Patronage of an Iranian Merchant under Shah Jahan ». Iranian Studies 36, 2 (2003), pp. 213-240. », Abstracta Iranica [En ligne], Volume 26 | 2005, document 230, mis en ligne le 08 décembre 2005, consulté le 25 septembre 2020. URL : http:// journals.openedition.org/abstractairanica/2757 ; DOI : https://doi.org/10.4000/abstractairanica.2757

Ce document a été généré automatiquement le 25 septembre 2020.

Tous droits réservés 


\section{« Of Jewels and Horses: the Career and Patronage of an Iranian Merchant under Shah Jahan ». Iranian Studies 36, 2 (2003), pp. 213-240.}

\section{Colin Mitchell}

Here, Elizabeth Lambourn contributes to a special issue of Iranian Studies on IndoPersian contacts with an article examining the patronage and construction of a hitherto unexamined mosque by a prominent and successful Iranian émigré named 'Alī Akbar Iṣfahānī in the Gujarati city of Cambay. Little remains of this Masjid-i Fath, built in 1656, except the four surrounding walls, on which we find marble mihräbs with inscriptions in both Persian and Arabic attesting to the building and patronage of this mosque by Ișfahānī. Lambourn contextualizes the construction of this edifice by comparing the design of the building with other Gujarati mosques built in the medieval and early modern periods. When combined with her conclusion that the stone intarsia found in the mihräbs was inspired by the pietra dure work found in nearby Mughal religious and imperial monuments, we find that this mosque was reflective of a syncretist trend whereby Gujarati artistry was combined with Mughal architecture under the auspices of Iranian patronage. Lambourn also sheds light on the career of 'Ali Akbar Ișfahānī, and we find that his transition from successful merchant - primarily dealing with horse trade - to Mughal-appointed city administrator was consistent with longstanding societal trends whereby Iranian merchants emigrated to the western coast of India and manipulated the flow of commercial traffic from the Persian Gulf through the Indian Ocean. 
INDEX

Thèmes : 4.2.1. Safavides et Qâjârs

\section{AUTEURS}

COLIN MITCHELL

Dalhousie University - Halifax 